\title{
PROFITABILITAS DAN PERTUMBUHAN PERUSAHAAN TERHADAP KEBIJAKAN DEVIDEN PADA PERUSAHAAN MANUFAKTUR DI INDONESIA
}

\author{
Oleh: \\ Eli Safrida \\ (Program Studi Akuntansi Jurusan Akuntansi Politeknik Negeri Medan)
}

\begin{abstract}
The purpose of this study was to analyze the effect of profitability on dividend policy, to analyze the effect of the company's growth to dividend policy, to analyze the effect on the company's profitability and growth dividend policy.

The object of research companies listed in Indonesia Stock Exchange the period 2008-2011. The number of samples is 26 companies, the samples were taken by using purposive sampling method. Tools of data analysis using linear regression.

The results obtained from the analysis of the data is positive and significant effect of profitability on dividend policy, growth companies positive but not significant effect on dividend policy, profitability and corporate growth and a significant positive effect on dividendpolicy.
\end{abstract}

Keywords: profitability, growth companies and dividend policy.

\section{Pendahuluan}

Investor sangat membutuhkan informasi untuk melakukan penilaian terhadap perusahaan. Kebijakan deviden merupakan salah satu informasi yang dibutuhkan oleh investor. Deviden merupakan salah satu keputusan penting untuk memaksimumkan nilai perusahaan disamping keputusan investasi dan struktur modal (keputusan pemenuhan dana). Manajemen mempunyai 2 alternatif perlakuan terhadap penghasilan bersih sesudah pajak (Earning After Tax) perusahaan yaitu: 1.dibagi kepada para pemegang saham perusahaan dalam bentuk dividen. 2.diinvestasikan kembali ke perusahaan sebagai laba ditahan (retained earning).

Biasanya sebagian EAT (Earning After Tax) dibagi dalam bentuk dividen dan sebagian lagi diinvestasikan kembali, oleh karena itu manajemen harus membuat kebijakan (dividen policy) tentang besarnya EAT yang dibagikan sebagai dividen.

Apabila perusahaan memutuskan untuk membagi laba yang diperoleh sebagai dividen berarti akan mengurangi jumlah laba ditahan yang akhirnya mengurangi sumber dana intern yang akan mengurangi sumber dana intern yang akan digunakan untuk mengembangkan perusahaan. Apabila perusahaan tidak membagikan labanya sebagai dividen akan bisa memperbesar sumber dana intern dan akan meningkatkan kemampuan perusahaan untuk mengembangkan perusahaan. Pertumbuhan perusahaan dan deviden merupakan hal yang sangat di 
inginkan oleh perusahaan atau pelaku ekonomi, tetapi merupakan tujuan yang berbeda. Untuk memperoleh pertumbuhan perusahaan harus menetapkan kebijakan deviden.

Profitabilitas adalah kemampuan menghasilkan laba (profit) selama periode tertentu dengan menggunakan aktiva yang produktif atau modal, baik modal secara keseluruhan maupun modal sendiri (Van Horn \& Wachowiez, 1997:148-149). Pendapat lain menyebutkan bahwa profitabilitas perusahaan merupakan salah satu indikator yang tercakup dalam informasi mengenai kinerja perusahaan jangka panjang. Kinerja keuangan tersebut dapat dilihat melalui analisis laporan keuangan. Menurut Brigham (1993:79) "Managerial Finance" mengemukakan profitabilitas sebagai berikut : "Profitability is the result of a large number of policies and decision”. Sartono (2001:119) mendefinisikan profitabilitas sebagai kemampuan perusahaan memperoleh laba dalam hubungan dengan penjualan, total aktiva produktif maupun modal sendiri. Rasio profitabilitas ini akan memberikan gambaran tentang tingkat efektifitas pengelolaan perusahaan. Semakin besar profitabilitas berarti semakin baik, karena kemakmuran pemilik perusahaan meningkat dengan semakin besarnya profitabilitas. Rasio profitabilitas terdiri atas Profit Margin, Basic Earning Power, Return On Assets, dan Return On Equity. Tingkat profitabilitas digunakan sebagai dasar untuk mengukur kinerja keuangan perusahaan, hal ini dilakukan mengingat daya tarik bisnis (business attractiveness) merupakan salah satu indikator penting dalam persaingan usaha, sedangkan indikator daya tarik bisnis dapat diukur dari profitabilitas usaha, seperti ROA, ROE dan NPM. Semakin tinggi rasio ini akan menarik pendatang baru untuk masuk dalam dunia usaha, sehingga pada kondisi persaingan tersebut akan membuat rate of return cenderung mengarah pada keseimbangan (Gale, 1972). Daya tarik bisnis yang semakin tinggi akan mendorong pendatang baru untuk masuk dalam dunia usaha sehingga laba abnormal lambat laun akan kembali menurun menuju laba normal.

Hal yang paling mudah dilakukan untuk menganilisa profitabilitas perusahaan adalah dengan menghubungkan laba bersih (pendapatan bersih) yang dilaporan terhadap total aset yang berada di bagian neraca. Laba bersih perusahaan diperoleh dari hasil pertandingan antara total pendapatan terhadap total biaya. Selain itu profitabilitas sangat tergantung dengan analisis ekonomi dan keberhasilan implementasi dari proyek investasi yang baru saja dilakukan. (Helfert, 1997:86)

Pertumbuhan perusahaan mengindikasikan kemampuan perusahaan dalam mempertahankan kelangsungan usahanya. Pertumbuhan (Growth) adalah seberapa jauh perusahaan menempatkan diri dalam sistem ekonomi secara keseluruhan atau sistem ekonomi untuk industri yang sama (Machfoedz, 1996: 108).

Pada umumnya, perusahaan yang tumbuh dengan cepat memperoleh hasil positif dalam artian pemantapan posisi di peta persaingan, menikmati penjualan yang meningkat secara signifikan dan diiringi oleh adanya peningkatan pangsa pasar. Perusahaan yang tumbuh cepat juga menikmati keuntungan dari citra positif yang diperoleh, akan tetapi perusahaan harus ekstra hati-hati, karena kesuksesan yang diperoleh menyebabkan perusahaan menjadi rentan terhadap adanya isu negatif. Beberapa hal yang perlu mendapat perhatian penting karena dapat merupakan sumber berita negatif yang menggambarkan kemampuan perusahaan untuk mempertahankan, mengembangkan dan membangun kecocokan 
kualitas dan pelayanan dengan harapan konsumen. Pertumbuhan cepat juga memaksa sumber daya manusia yang dimiliki untuk secara optimal memberikan kontribusinya. Agar pertumbuhan cepat tidak memiliki arti pertumbuhan biaya yang kurang terkendali, maka dalam mengelola pertumbuhan, perusahaan harus memiliki pengendalian operasi dengan penekanan pada pengendalian biaya (Susanto, 1997: 185-187).

Menurut Modigliani dan Miller tahun 1961 dalam buku (Arifin, 2005: 5) kebijakan deviden tidak relevan. Pada pasar modal yang sempurna, perusahaan akan dapat dengan cepat dan murah untuk menerbitkan saham baru kapan saja sesuai dengan keinginan. Sehingga jika perusahaan kekurangan dana untuk melakukan investasi karena perusahaan tersebut telah menggunakan sebagian labanya untuk pembayaran deviden, maka perusahaan tersebut dapat mencari pengganti dana tersebut di pasar modal.

Pembayaran deviden yang semakin besar juga akan mengurangi kemampuan perusahaan untuk investasi sehingga justru akan menurunkan tingkat pertumbuhan perusahaan dan selanjutnya akan menurunkan nilai saham. Dengan demikian penundaan pembayaran dividen kepada pemegang saham untuk keperluan investasi yang menguntungkan (apabila return lebih besar dari biaya modal) akan menaikkan harga saham (pada pasar modal yang sempurna). Pada pasar modal yang tidak sempurna, pembayaran dividen untuk menaikkan nilai saham akan sangat merugikan karena harus membayar biaya fluktuasi.

Dividend Signaling Model berasumsi bahwa deviden diperlukan untuk memberikan informasi positif dari manajer yang well-informed ke pemegang saham yang poorly-informed. Munculnya manajer yang well-informed dan pemegang saham yang pooly-informed merupakan fenomena pasar modal modern. Pembayaran deviden merupakan sesuatu yang memberatkan perusahaan karena akan mengurangi jumlah dana yang tersedia untuk investasi. Di sisi lain, pembayaran deviden juga merugikan pemegang saham karena mereka harus membayar pajak atas deviden yang dibayarkan tersebut.

Model signaling konsisten dengan observasi bahwa devidend payout berhubungan dengan profitabilitas dan perusahaan yang memiliki free cash flows besar akan membayar jumlah deviden besar. Model signaling juga konsisten dengan observasi bahwa pasar merespon dengan harga yang meningkat signifikan pada saat inisiasi dan peningkatan deviden serta menurun dalam jumlah besar saat ada pemotongan deviden.

Faktor lain yang berpengaruh terhadap pembayaran deviden adalah tingkat pertumbuhan aset, meningkatnya tingkat pertumbuhan aset maka pengaruhnya akan menurunkan deviden yang dibayarkan.

Berdasarkan uraian diatas maka rumusan masalah dalam penelitian ini adalah apakah profitabilitas dan pertumbuhan perusahaan berpengaruh terhadap kebijakan deviden pada perusahaan manufaktur di Indonesia.

\section{Kajian Pustaka}

Brigham dan Gapenski (1999) menyatakan bahwa setiap perubahan dalam kebijakan pembayaran deviden akan memiliki 2 dampak yang berlawanan. Jika 
deviden akan dibayarkan semua, kepentingan cadangan akan terabaikan. Jika laba ditahan tidak dibagikan maka kepentingan pemegang saham juga terabaikan.

Penelitian yang dilakukan oleh Deitiana (2008) dengan judul faktor-faktor yang mempengaruhi kebijakan deviden kas. Objek penelitian adalah perusahaan manufaktur dan non manufaktur selain bank dan lembaga keuangan lainnya yang terdaftar di Bursa Efek Indonesia dari tahun 2003-2007. Hasilnya adalah tidak terdapat pengaruh yang signifikan debt to equity ratio, return on investment, current ratio, net profit margin, inventory turnover dan return on equity terhadap devidend payout ratio, tetapi ditemukan pengaruh yang signifikan earning per share dan price earning ratio terhadap devidend payout ratio.

Penelitian yang dilakukan oleh Deitiana (2009) dengan judul pengaruh ratio keuangan, pertumbuhan penjualan dan deviden terhadap harga saham. Objek penelitian perusahaan LQ 45 periode 2004-2008 yaitu 45 dan mengeluarkan deviden secara tetap adalah 20 perusahaan. Hasilnya menunjukkan bahwa profitabilitas berpengaruh signifikan terhadap harga saham, sedangkan likuiditas, deviden, dan pertumbuhan penjualan tidak berpengaruh terhadap harga saham.

Suharli (2007) melakukan penelitian dengan judul pengaruh profitabilitas dan investment opportunity set terhadap kebijakan deviden tunai dengan likuiditas sebagai variabel penguat pada perusahaan yang terdaftar di Bursa Efek Jakarta 2002-2003. Hasilnya profitabilitas berpengaruh terhadap kebijakan deviden, likuiditas yang digunakan sebagai variabel penguat (variabel moderating) memberikan hasil yang signifikan pada $\alpha 0.10$ dalam mempengaruhi profitabilitas dan kesempatan investasi. Dengan demikian kebijakan pembagian deviden ditentukan oleh profitabilitas dan diperkuat oleh likuiditas.

Arilaha A (2007) melakukan penelitian dengan judul pengaruh free cash flow, profitabilitas, likuiditas dan leverage terhadap kebijakan deviden pada perusahaan manufaktur yang terdaftar di Bursa Efek Indonesia tahun 2004-2007. Hasilnya profitabilitasberpengaruh terhadap kebijakan deviden, namun ditemukan likuiditas dan leverage tidak berpengaruh terhadap kebijakan deviden.

Islamiyah (2012) melakukan penelitian dengan judul pengaruh free cash flow, profitabilitas, likuiditas, leverage dan growth terhadap kebijakan deviden pada perusahaan manufaktur yang terdaftar di Bursa Efek Indonesia. Hasilnya secara parsial free cash flow, profitabilitas, likuiditas, leverage dan growth tidak berpengaruh signifikan terhadap kebijakan deviden.

Berdasarkan teori dan kerangka pemikiran diatas, maka hipotesis dalam penelitian ini adalah sebagai berikut:

$\mathrm{H}_{1}$ : Profitabilitas berpengaruh terhadap kebijakan deviden

$\mathrm{H}_{2}$ : Pertumbuhan Perusahaan berpengaruh terhadap kebijakan deviden

$\mathrm{H}_{3}$ : Profitabilitas dan Pertumbuhan Perusahaan berpengaruh terhadap kebijakan deviden

\section{Metode Penelitian}

Sesuai dengan tujuan penelitian yaitu menguji hipotesis, maka desain penelitian yang digunakan dalam penelitian ini adalah desain kausal. Penentuan populasi dalam penelitian ini adalah seluruh perusahaan manufaktur di Bursa Efek Jakarta. Berdasarkan informasi yang diperoleh dari Indonesian Capital Market Directory (www.idx.com) jumlah perusahaan manufaktur yang terdaftar tahun 2011 adalah 138 perusahaan. 
Penentuan sampel dalam penelitian ini berdasarkan pada metode purposive sampling, dimana sampel perusahaan dipilih berdasarkan pada kriteria tertentu. Adapun kriteria yang digunakan untuk memilih sampel adalah perusahaan manufaktur yang terdaftar di Bursa Efek Jakarta sesuai dengan pengklasifikasian Indonesian Capital Market Director yang Perusahaan manufaktur yang menerbitkan laporan keuangan dari tahun 2008-2011 secara berturut-turut. Adapun proses pengambilan sampelnya adalah sebagai berikut:

Tabel Proses Pengambilan Sampel

\begin{tabular}{|l|l|}
\hline \multicolumn{1}{|c|}{ Keterangan } & Jumlah \\
\hline $\begin{array}{l}\text { Perusahaan manufaktur yang terdaftar di bursa efek Indonesia dari tahun } \\
\text { 2008-2011 }\end{array}$ & 138 \\
\hline $\begin{array}{l}\text { Perusahaan manufaktur yang tidak menerbitkan laporan keuangan secara } \\
\text { berturut-turut dari tahun 2008-2011 }\end{array}$ & 30 \\
\hline $\begin{array}{l}\text { Perusahaan manufaktur yang tidak membayar deviden dari tahun 2008- } \\
2011\end{array}$ & 60 \\
\hline Perusahaan yang memiliki pertumbuhan aset negatif & 22 \\
\hline Perusahaan yang menjadi sampel dalam penelitian & 26 \\
\hline
\end{tabular}

\section{Variabel Penelitian}

Dalam Penelitian ini, yang dijadikan sebagai variabel dependen adalah kebijakan deviden $(\mathrm{Y})$, sedangkan variabel independen dalam penelitian ini adalah profitabilitas $\left(\mathrm{X}_{1}\right)$ dan pertumbuhan perusahaan $\left(\mathrm{X}_{2}\right)$.

\section{Kebijakan Deviden (Y)}

Persentase deviden yang dibagi dari EAT (Earning After Tax). Adapun rumus dari kebijakan deviden addalah sebagai berikut:

\section{Profitabilitas $\left(\mathbf{X}_{1}\right)$}

$$
D P R=\frac{\text { Devidenyangdibagi }}{E A T}
$$

Profitabilitas diukur dengan menggunakan selisih antara penjualan dengan harga pokok penjualan terhadap penjualan. Profitabilitas adalah kemampuan perusahaan memperoleh laba dalam hubungannya dengan penjualan (Santoso, 2001:122).

\section{Pertumbuhan Perusahaan $\left(\mathbf{X}_{2}\right)$}

$$
\text { GrossProfitMargin }=\frac{\text { Penjualan }- \text { HargaPokokPenjualan }}{\text { Penjualan }}
$$

Pertumbuhan perusahaan diukur dengan menggunakan perubahan total aktiva. Pertumbuhan perusahaan adalah selisih total aktiva yang dimiliki oleh perusahaan pada periode sekarang dengan periode sebelumnya terhadap total aktiva periode sebelumnya.

$$
\text { Perubahan Total Aset }=\frac{\text { Total Aset }_{t}-\text { Total Aset }_{t-1}}{\text { Total Aset }_{t-1}}
$$

Teknik analisis data yang dilakukan dalam penelitian ini adalah menggunakan model regresi. Untuk dapat melakukan analisis dengan model 
regresi, data harus good and fit. Penilaian good and fit dianalisis dengan uji kualitas data. Adapun uji kualitas data terdiri dari statistik deskriptif dan asumsi klasik.

Pengujian hipotesis dalam penelitian ini akan menguji apakah profitabilitas dan pertumbuhan perusahaan berpengaruh terhadap kebijakan deviden. Teknik statistik yang digunakan adalah regresi linier. Pengujian hipotesis dengan menggunakan regresi sederhana diterapkan untuk hipotesis 1 dan 2 karena hanya menguji pengaruh secara parsial antara variabel independen (profitabilitas dan pertumbuhan perusahaan) terhadap satu variabel dependen (kebijakan deviden). Pengujian hipotesis 3 dengan menggunakan model regresi berganda, karena akan menguji pengaruh secara bersama-sama antara variabel independen (profitabilitas dan pertumbuhan perusahaan) terhadap satu variabel dependen (kebijakan deviden). Apabila nilai koefisien profitabilitas yang diukur dengan gross profit margin signifikan, maka akan menunjukkan bahwa profitabilitas berpengaruh terhadap kebijakan deviden. Nilai koefisien pertumbuhan perusahaan yang diukur dengan perubahan total aktiva yang signifikan menunjukkan bahwa terdapat pengaruh antara pertumbuhan perusahaan terhadap kebijakan deviden.

Pengujian hipotesis 1 apakah profitabilitas berpengaruh terhadap kebijakan deviden, dapat dilakukan dengan teknik regresi linier sederhana. Adapun langkah-langkah yang dilakukan sebagai berikut:

1. Membuat Formulasi Hipotesis:

$\mathrm{H}_{1:} \mathrm{b}_{1} \neq 0$, profitabilitas berpengaruh terhadap kebijakan deviden

2. Menentukan Tingkat Signifikansi.

Untuk memperoleh nilai signifikansi, menggunakan taraf nyata $(\alpha) 5 \%$.

3. Dasar pengambilan keputusan

a. $\rho$-value $<0.05$, maka $\mathrm{H}_{1}$ berpengaruh

b. $\rho$-value $>0.05$, maka $\mathrm{H}_{1}$ tidak berpengaruh

Pengujian hipotesis 2 apakah pertumbuhan perusahaan berpengaruh terhadap kebijakan deviden, dapat dilakukan dengan teknik regresi linier sederhana. Adapun langkah-langkah yang dilakukan sebagai berikut:

1. Membuat Formulasi Hipotesis:

$\mathrm{H}_{2}$ : $\mathrm{b}_{2} \neq 0$, pertumbuhan perusahaan berpengaruh terhadap kebijakan deviden

2. Menentukan Tingkat Signifikasi.

Untuk memperoleh nilai signifikansi, menggunakan taraf nyata $(\alpha) 5 \%$.

3. Dasar pengambilan keputusan

$\begin{array}{ll}\text { a. } & \rho \text {-value }<0.05, \text { maka } \mathrm{H}_{2} \text { berpengaruh } \\ \text { b. } & \rho \text {-value }>0.05, \text { maka } \mathrm{H}_{2} \text { tidak berpengaruh }\end{array}$

Pengujian hipotesis 3 apakah profitabilitas dan pertumbuhan perusahaan, berpengaruh terhadap kebijakan deviden, dapat dilakukan dengan teknik regresi linier berganda. Adapun langkah-langkah yang dilakukan adalah sebagai berikut:

1. Membuat Formulasi Hipotesis:

$\mathrm{H}_{3}: \mathrm{b}_{3} \neq 0$, profitabilitas dan pertumbuhan perusahaan berpengaruh terhadap kebijakan deviden

2. Menentukan Tingkat Signifikansi

Untuk memperoleh nilai signifikansi, menggunakan taraf nyata $(\alpha) 5 \%$.

3. Dasar pengambilan keputusan

a. $\rho$-value $<0.05$, maka $\mathrm{H}_{3}$ berpengaruh 
b. $\rho$-value $>0.05$, maka $\mathrm{H}_{3}$ tidak berpengaruh

\section{Hasil dan Pembahasan}

Setelah diajukan pengujian asumsi klasik, maka selanjutnya dilakukan pengujian hipotesis 1 dengan menggunakan anilisis regresi linear sederhana. Pengujian hipotesis 1 dilakukan untuk menguji apakah profitabilitas berpengaruh terhadap kebijakan deviden. Hasil pengujian hipotesis dapat dilihat pada tabel berikut ini:

Tabel Nilai R Square Hipotesis 1

Model Summary

\begin{tabular}{|l|l|l|l|l|}
\hline Model & $\mathbf{R}$ & $\begin{array}{l}\mathbf{R} \\
\text { Square }\end{array}$ & $\begin{array}{l}\text { Adjusted R } \\
\text { Square }\end{array}$ & $\begin{array}{l}\text { Std. Error of the } \\
\text { Estimate }\end{array}$ \\
\hline 1 & $.527^{\mathrm{a}}$ & .278 & .268 & .20374477 \\
\hline
\end{tabular}

a. Predictors: (Constant), Profitabilitas (X1)

b. Dependent Variable: Kebijakan Deviden (Y)

Sumber: Data diolah

Nilai $\mathrm{R}$ square $\left(\mathrm{R}^{2}\right)$ atau nilai koefisien determinan digunakan untuk mengukur seberapa jauh kemampuan model dalam menerangkan variasi variabel dependen. Nilai $\mathrm{R}^{2}$ adalah diantara nol dan satu. Nilai $\mathrm{R}^{2}$ yang kecil berarti kemampuan variabel independen dalam menjelaskan variasi variabel dependen sangat terbatas. Nilai yang mendekati satu berarti variabel independen memberikan hampir semua informasi yang dibutuhkan

Hasil penelitian ini menunjukkan bahwa profitabilitas berpengaruh secara positif terhadap kebijakan deviden, yang dapat dilihat dari nilai koefisien regresi profitabilitas sebesar 0.832 dengan signifikansi 0.000 , yang berarti bahwa setiap adanya kenaikan selisih antara penjualan dengan harga pokok penjualan terhadap penjualan sebagai kemampuan perusahaan memperoleh laba dalam hubungannya dengan penjualan sebesar 1 satuan akan berpengaruh pada peningkatan kemampuan pihak manajemen perusahaan melakukan pembayaran deviden sebesar 0.832 satuan kepada para pemegang saham. Hasil temuan ini terbukti menerima hipotesis $1\left(\mathrm{H}_{1}\right)$ yang menyatakan bahwa profitabilitas berpengaruh terhadap kebijakan deviden, dan sekaligus menjawab perumusan masalah pertama penelitian ini.

Hasil penelitian ini konsisten dengan temuan yang dilakukan oleh suharli (2007), yang menyatakan bahwa profitabilitas berpengaruh terhadap kebijakan deviden.

Hasil penelitian ini konsisten dengan temuan Arilaha A (2007), yang menyatakan bahwa profitabilitas berpengaruh terhadap kebijakan deviden pada perusahaan manufaktur yang terdaftar di Bursa Efek Indonesia tahun 2004-2007.

Hasil penelitian ini bertolak belakang dengan penelitian yang dilakukan oleh Deitiana (2008), yang menyatakan bahwa tidak terdapat pengaruh antara net profit margin terhadap devidend payout ratio. Penelitian tersebut sejalan dengan penelitian yang dilakukan oleh Islamiyah (2012), yang menyatakan bahwa profitabilitas tidak berpengaruh terhadap kebijakan deviden.

Hasil penelitian ini juga sejalan dengan model signaling yang telah konsisten dengan observasi bahwa deviden yang dibayarkan pihak manajemen perusahaan kepada para pemegang saham berhubungan dengan profitabilitas dan 
perusahaan yang memiliki free cash flows besar juga akan membayar jumlah deviden yang besar. Dengan demikian informasi positif pihak manajemen perusahaan mengenai pembayaran deviden kepada para pemegang saham. Pembayaran deviden merupakan sinyal bagi para pemegang saham mengenai prospek perusahaan dimasa mendatang. Perusahaan yang mampu melakukan pembayaran deviden berarti perusahaan tersebut memiliki pendapatan dan free cash flow yang baik. Perusahaan yang memiliki profitabilitas yang baik maka perusahaan tersebut akan membayar deviden yang tinggi.

Hasil penelitian ini menunjukkan bahwa pertumbuhan perusahaan berpengaruh positif namun tidak signifikan terhadap kebijakan deviden, yang dapat dilihat dari nilai koefisien regresi pertumbuhan perusahaan sebesar 0.150 dengan signifikansi 0.463 , yang berarti bahwa setiap peningkatan pertumbuhan perusahaan sebesar 1 satuan maka akan berpengaruh pada pembayaran deviden dari pihak manajemen perusahaan sebesar 0.150 satuan kepada para pemegang saham. Namun peningkatan pertumbuhan perusahaan tersebut tidak mempengaruhi besaran deviden yang dibayarkan kepada para pemegang saham. Hasil temuan ini terbukti menolak hipotesis $2\left(\mathrm{H}_{2}\right)$ yang menyatakan bahwa pertumbuhan perusahaan berpengaruh terhadap kebijakan deviden, dan sekaligus menjawab rumusan masalah kedua penelitian ini.

Hasil penelitian ini konsisten dengan penelitian yang dilakukan oleh Suharli (2007) pada perusahaan yang terdaftar di Bursa Efek Jakarta periode 2002-2003 dan Islamiayah (2012) yang menyatakan bahwa tidak adanya pengaruh antara pertumbuhan perusahaan dengan kebijakan deviden.

Hasil temuan ini tidak konsisten dengan temuan yang dilakukan oleh Sulistiyowati.,et al (2010) yang menyatakan bahwa tingkat pertumbuhan perusahaan merupakan salah satu faktor yang mempengaruhi kebijakan deviden. Dengan menggunakan konsep Pecking Order Theory semakin cepat tingkat pertumbuhan suatu perusahaan, maka semakin besar kebutuhan dana yang diperlukan untuk membiayai pertumbuhan tersebut. Semakin besar kebutuhan dana untuk waktu mendatang maka perusahaan lebih senang untuk menahan labanya daripada membayarkannya sebagai dividen kepada pemegang saham.

Hasil penelitian ini menunjukkan bahwa profitabilitas dan pertumbuhan perusahaan berpengaruh terhadap kebijakan deviden, yang dapat dilihat dari koefisien regresi profitabilitas sebesar 0.830 dan koefisien regresi pertumbuhan perusahaaan sebesar 0.136 dengan signifikansi 0.000 , yang berarti bahwa setiap ada kenaikan selisih penjualan dengan harga pokok penjualan terhadap penjualan 1 satuan maka akan berpengaruh pada pembayaran deviden dari pihak manajemen perusahaan kepada para pemegang saham sebesar 0.830, setiap ada kenaikan pertumbuhan perusahaan sebesar 1 satuan maka akan berpengaruh pada peningkatan pembayaran deviden dari pihak manajemen perusahaan kepada para pemegang saham sebesar 0.136. Hasil temuan ini terbukti menerima hipotesis 3 $\left(\mathrm{H}_{3}\right)$ yang menyatakan bahwa profitabilitas dan pertumbuhan perusahaan berpengaruh terhadap kebijakan deviden.

Hasil temuan sejalan dengan model signaling yang menyatakan bahwa perusahaan yang memiliki profitabilitas yang tinggi dan pertumbuhan perusahaan yang meningkat akan cenderung melakukan pembayaran deviden yang tinggi pula. Tetapi ketika perusahaan memiliki pertumbuhan perusahaan yang menurun 
maka pihak manajemen perusahaan cenderung tidak akan membayarkan devidennya kepada para pemegeng saham.

Tabel Pengamatan Deviden Yang Dibagikan, Earning After Tax, Penjualan, Harga Pokok Penjualan, Total Aset

\begin{tabular}{|c|c|c|c|}
\hline \multirow{2}{*}{ Keterangan } & \multicolumn{3}{|c|}{ Tahun } \\
\hline & 2009 & 2010 & 2011 \\
\hline $\begin{array}{l}\text { Deviden yang } \\
\text { dibagikan }\end{array}$ & $254,108,273,929$ & $321,057,569,165$ & $413,015,990,308$ \\
\hline Earning after tax & $630,912,564,545$ & $770,442,817,022$ & $889,338,701,668$ \\
\hline Penjualan & $5,093,099,658,895$ & $5,571,621,165,477$ & $6,460,237,372,367$ \\
\hline $\begin{array}{l}\text { Harga pokok } \\
\text { penjualan }\end{array}$ & $3,292,406,504,994$ & $3,526,820,217,360$ & $4,228,022,809,454$ \\
\hline Total aset & $4,888,973,865,173$ & $5,556,946,995,901$ & $6,468,703,304,398$ \\
\hline $\begin{array}{l}\text { Kebijakan } \\
\text { Deviden }(\%)\end{array}$ & 36.359 & 35.747 & 40.569 \\
\hline Profitabilitas (\%) & 33.438 & 34.069 & 33.173 \\
\hline $\begin{array}{l}\text { Pertumbuhan } \\
\text { Perusahaan }(\%)\end{array}$ & 10.784 & 12.666 & 16.946 \\
\hline
\end{tabular}

Sumber: Data diolah

Berdasarkan pengamatan dari tabel diatas, deviden yang dibagikan, earning after tax, penjualan harga pokok penjualan dan total aset yang dimiliki oleh perusahaan manufaktur yang terus meningkat memberikan bukti empiris bahwa pihak manajemen perusahaan cenderung memberikan informasi yang baik kepada para pemegang saham. Hal ini menjelaskan bahwa pihak manajemen perusahaan memberikan sinyal kepada para pengguna laporan keuangan, sinyal ini bisa berupa informasi mengenai segala sesuatunya yang telah dilakukan pihak manajemen perusahaan untuk merealisasikan segala keinginan para pemilik. Dengan demikian pihak manajemen perusahaan memberikan informasi kepada para pemegang saham untuk mengurangi asimetris informasi. Selain itu juga, diperkirakan juga pihak manajemen perusahaan selalu memberikan informasi terkait dengan situasi dan kondisi perusahaan kepada pemilik dan pihak luar perusahaan. informasi yang disampaikan oleh pihak manajemen perusahaan merupakan good news bagi pihak pengguna laporan keuangan. Selain itu juga, pasar merespon dengan baik dan cepat ketika terjadi pengumuman deviden, sehingga para pemegang saham semakin yakin bahwa perusahaan tersebut memiliki prospek yang baik untuk dapat menghasilkan laba dimasa yang akan datang yang bisa dijadikan sebagai laba ditahan untuk pembayaran deviden bagi perusahaan yang memiliki eksistensi yang tinggi. Oleh karena itu pembayaran deviden menunjukkan kinerja yang baik bagi pihak manajemen perusahaan. perusahaan yang mampu meningkatkan pembayaran deviden berarti perusahaan tersebut memiliki cash flows yang baik yang dapat mendukung untuk pembayaran deviden kepada para pemegang saham. Sehingga para pemegang saham bisa memperoleh tingkat pengembalian investasi atas investasi yang dilakukannya. 


\section{Simpulan}

Berdasarkan hasil analisis dan pembehasan dapat diambil beberapa kesimpulan sebagai berikut:

1. Profitabilitas berpengaruh positif dan signifikan terhadap kebijakan deviden. Hal ini berarti perusahaan yang memiliki pendapatan dan free cash flows yang baik memiliki kemungkinan besar akan membayarkan deviden dari pihak manajemen perusahaan kepada para pemegang saham yang besar pula.

2. Pertumbuhan perusahaan berpengaruh positif namun tidak signifikan terrhadap kebijakan deviden. Pertumbuhan perusahaan bukan merupakan hal yang amat harus diperhatikan oleh para pemegang saham. Meskipun pertumbuhan perusahaan merupakan salah satu faktor yang mempengaruhi kebijakan deviden.

3. Profitabilitas dan pertumbuhan perusahaan berpengaruh positif dan signifikan terhadap kebijakan deviden. Hal ini berarti pihak manajemen perusahaan memberikan informasi yang langsung di respon oleh pasar dengan cepat dan baik ketika ada pengumuman deviden, pihak manajemen perusahaan memberikan informasi kepada para pengguna informasi segala sesuatunya mengenai keadaan dan situasi perusahaan, informasi yang disajikan oleh pihak manajemen kepada para pengguna laporan keuangan merupakan hal penting untuk mengurangi asimetri informasi. Pembayaran deviden memperlihatkan kinerja dan artinya perusahaan tersebut memiliki kemampuan pendapatan dan free cash flows yang baik dan juga tingkat pertumbuhan yang baik pula.

\section{Saran}

Berdasarkan kesimpulan dan keterbatasan penelitian, maka perlu dilakukan penyempurnakan terhadap penelitian yang dilakukan. Adapun saran untuk peneliti selanjutnya adalah sebagai berikut:

1. Untuk peneliti lanjutan disarankan untuk menggunakan sampel jenis seluruh di Bursa Efek Indonesia, dan periode penelitian lebih panjang agar mendapatkan hasil yang lebih digeneralisir.

2. Untuk peneliti lanjutan dapat menambahkan variabel lain seperti investment opportunity set, leverage, likuiditas, free cash flows yang diprediksi bisa mempengaruhi kebijakan deviden baik secara langsung maupun tidak langsung.

\section{Daftar Pustaka}

Arief, Sritua. 2006. Metodologi Penelitian Ekonomi. Jakarta: UI Press

Arifin, Zaenal. 2005. Teori Keuangan dan Pasar Modal. Edisi Pertama. Yogyakarta: Ekonisia

Arilaha, A.M. April 2009. Pengaruh Free Cash Flow, Profitabilitas, Likuiditas dan Leverage Terhadap Kebijakan Deviden. Jurnal Keuangan dan Perbankan Vol 13, No 1, Hal:78-87 or www.google.com/search

Brigham, E.F. 1993. Managerial Finance. Hinsdale:The Dyden Press. 
Brigham, E.F., and L.C. Gapenski. 1999. Financial Management Theory and Practice. United Stated Of America

Deitiana, Tita. April 2009. Faktor-Faktor yang Mempengaruhi Kebijakan Pembayaran Deviden Kas. Jurnal Bisnis dan Akuntansi. Vol 11, No.1, Hal:57-64 or www. Google.com/search

Deitiana, Tita. April 2011. Pengaruh Ratio Keuangan, Pertumbuhan Penjualan dan deviden terhadap Kebijakan Deviden. Jurnal Bisnis dan Akuntansi. Vol 13, No.1, Hal:57-66 or www.Google.com/search

Gale, B.T. 1972. Market Share and Rate of Return. The Review of Economics and Statistik, 412-413.

Ghozali, Imam. 2001. Aplikasi Analisis Multivariate dengan Program SPSS. Edisi Ketiga. Universitas Diponegoro.

Hakim, Abdul. 2004. Statistik Deskriptif Untuk Ekonomi dan Bisnis. Cetak Kedua. Yogyakarta: Ekonisia.

Helfert, E.A. 1997. Teknik analisis Keuangan. Penerjemah Herman Wibowo. Edisi kedelapan. Jakarta: Erlangga

Islamiyah, Rizki. 2012. Pengaruh Free Cash Flow, Profitabilitas, Likuiditas, Leverage dan Growth Terhadap Kebijakan Deviden. www.google.com/search

Machfoedz, Mas'ud. 1996. Akuntansi Manajemen Perencanaan dan Pembuatan Keputusan Jangka Pendek. Edisi Kelima. Buku 1. Yogyakarta: STIE-Widya Wiwaha.

Santoso, Singgih. 2006. Menguasai Statistik Di Era Informasi Dengan SPSS 15. Jakarta: Elex Media Komputindo

Sartono, R.A. 2001. Manajemen Keuangan Teori dan Aplikasi. Edisi 4. Yogyakarta: BPFE

Suharli, Michell. Mei 2007. Pengaruh Profitabilitas dan Investment Oppurtunity Set terhadap Kebijakan Deviden Tunai. Jurnal Akuntansi dan Keuangan. Vol 9, No 1, Hal:9-17 or www.google.com/search

Sulistyowati, I., R.Anggraini, dan T.H. Utaminingtyas. 2010. Pengaruh Profitabilitas, Leverage dan Growth terhadap Kebijakan Deviden dengan Good Corporate Governance Sebagai Variabel Intervening. Simposium Nasional Akuntansi XII Purwokerto.

Susanto. 1997. Manajemen Aktual Topik-topik Aktual Manajemen Dalam Riak Perubahan. Jakarta: Grasindo.

Umar, Husein. 2000. Metode Penelitian Untuk Skripsi dan Tesis Bisnis. Cetak 3. Jakarta: Raja Grafindo Persada.

Van Horne, James C., \& Jhon M, Wachowicz Jr. 1997. Prinsip-Prinsip Manajemen Keuangan. Edisi Kesembilan. Simon \& Schuter (Asia) Pte. Ltd 